\title{
Kognitywizm a komunikatywizm - dwa bieguny współczesnego językoznawstwa. Dyskusja okrągłego stołu
}

\section{Cognitivism and Communicativism - Two Opposite Poles of Contemporary Linguistics. Round Table Discussion}

\begin{abstract}
Aleksander Kiklewicz: Szanowni Państwo, wyczerpaliśmy program pierwszej części naszego spotkania - wszystkie zaplanowane referaty zostały wygłoszone. Teraz przejdziemy do dyskusji. Zaproponowałbym następujący porządek: najpierw poproszę uczestników „okrągłego stołu” o wypowiedzenie się na temat wszystkich referatów. Później - o ile pozwoli na to czas - udział w dyskusji wezmą też nasi słuchacze. Może zaczniemy od Pani Profesor Jolanty Antas, która już zasygnalizowała zainteresowanie niektórymi opiniami wygłoszonymi przez Profesora Awdiejewa.
\end{abstract}

Jolanta Antas: Ja powiem tak: jakoś nie widzę konfliktu między kognitywizmem a komunikatywizmem rozumianym jako rozwijanie pewnych teorii pragmalingwistycznych, wręcz uważam, że w ducha językoznawstwa kognitywnego jest wyraźnie wpisane to, że granice między semantyką a pragmatyką są płynne i że właściwie ich nie ma.

Od razu odniosę się do referatu Pani Profesor Bacz. Mnie się bardzo podobało to uruchamianie potencji znaczeniowej, o którym Pani mówiła w koncepcji Guillaume' a, bo myślę, że to jest bardzo bliskie próbie łączenia myśli kognitywnej w sensie konceptualizacji i aktualizacji komunikacyjnej danej wiedzy. W kognitywizmie mówi się, że nie ma jakiegoś jednoznacznego znaczenia i że nie wszystkie znaczenia, możliwości językowe potencji semantycznej jakichś wyrazów, są równocześnie przywoływane; nie będziemy się spierać o zdanie.... Bo jeśli Guillaume opracował czasownik, to myślę, że „zdaniowość” była tutaj bardzo bliska, również w sensie orzekalności. I właśnie ta stała suma wszystkich możliwych aktualizacji, o których Pani Profesor mówiła, ta suma mnie trochę niepokoi - że to jest suma, niech to będzie jakiś iloczyn związany z doświadczeniem, to by było bliższe. Kognitywiści by powiedzieli, że dane znaczenie jest profilowane $\mathrm{w}$ określonym momencie $\mathrm{i}$ to $\mathrm{w}$ dodatku 
jedno - nie wszystkie możliwości są przywoływane właśnie ze względu na kontekst komunikacyjny i relewantność tej informacji.

Z kolei co do postawy kolegów reprezentujących punkt widzenia komunikatywizmu, my się w niektórych punktach zgadzamy. Szczególnie zgadzamy się w założeniach teoretycznych. Na przykład myślę, że zgodziliby się koledzy ze mną, że trochę sztuczna jest próba w ogóle oddzielenia płaszczyzny ideacyjnej od interpersonalnego ustosunkowania, że się tego w ogóle nie da zrobić. Takie jest moje doświadczenie. Czyli znowu zgodziłabym się z propozycją Guillaume'a. Nie spierajmy się o to, czy język powstał jako wyraz pierwotnej myśli i dopiero potem stał się komunikacyjny, bo ja myślę, że te procesy zachodzą równocześnie. Nikt nie siedział sobie w kąciku i najpierw nie tworzył struktur wypowiedzeniowych własnych myśli, tylko jakby chciał dać wyraz swoim procesom myślenia i stąd próbował znaleźć sposoby referencyjne i w komunikacji powstawały odniesienia semantyczne, czyli krótko mówiąc: bardzo bym się bała utożsamiania faktu powstania myślenia w momencie ukształtowania całości struktury językowej.

Natomiast wracając do dynamizmu znaczenia potencjalnego u Guillaume'a. Podobało mi się dynamiczne przywoływanie pewnych profili potencjalnych, semantycznych - słów czy wyrażeń. Tu znowu wracam do kolegów komunikatywistów - ja się boję strasznie tego wyrażenia, że coś jest trywialne, coś jest standardem nie wnoszącym nic ciekawego informacyjnie, a coś innego jest interpretacją. Dlatego, że reinterpretacja standardów jest na przykład przywołaniem wielu nowych asumpcji i ja się takiej interpretacji boję. Teoria relewancji już to pokazywała, że ja nie robię tak: jeżeli chcę zinterpretować jakiś standard, to powołuję cały szereg nowych asumpcji, muszę je wszystkie przywołać, przebierać w nich, żeby wreszcie jedną z nich wybrać. To mi się wydaje za dużo; czegoś takiego my nie robimy, że przywołujemy właśnie tę najbardziej relewantną asumpcję i w dodatku wszystko jest osadzone w określonej domenie poznawczej, do tego się sprowadza. A domena poznawcza jest wyznaczana pewną relewantnością, pewnym komunikacyjnym celem bardzo określonym, najbliższym. Powiem tak: kontekst, który niby miał dawać reinterpretację, nie jest przywoływany za wypowiedzią, tylko on z wypowiedzią pojawia się równocześnie; nie da się po prostu ich oddzielić. Dlatego nie widzę potrzeby tworzenia całej masy niby potencjalnych, otwartych argumentów, które i tak w danej sytuacji nie będą jakby przydatne, bo stworzy się standardowe schematy do wypełnienia, które jeszcze otworzą nowe potencjalne możliwości. Wcześniej był podany ten przykład, „ptaki lecą”, jako trywialny. Ani trochę nie jest trywialny. 
Aleksy Awdiejew: Powiedziałem „ptaki latają”. Zdanie „ptaki lecą” nie jest trywialne.

Jolanta Antas: No dobrze „ptaki latają”. Chodzi o to, że nikt zazwyczaj nie wypowiada podobnych stwierdzeń, ale jeśli już je wypowie, stają się wtedy nietrywialne.

Aleksy Awdiejew: Otóż to, będziemy szukać celu komunikacyjnego i reinterpretować.

Jolanta Antas: Chodzi mi o to, iż stwierdzacie Państwo, że sformułowanie ,ptaki latają” jest trywialne.

Aleksy Awdiejew: Nie twierdzimy, że każde użycie tego sformułowania jest trywialne. Trzeba jednak odpowiedzieć na pytanie, po co zostało ono użyte. Mógłbym na przykład powiedzieć, że mam dzisiaj buty na sobie - bez zastanowienia się, po co to powiedziałem. Wtedy rzeczywiście byłoby to trywialne.

Jolanta Antas: Tak, ale nie przyjdzie nikomu przecież do głowy bez przerwy oznajmiać, że tu są lampy, tam stoją szafy, ja mam buty na sobie, założyłem marynarkę, tutaj są ludzie... To byłoby trywialne, gdybyśmy używali konstatacji! Ale jeżeli mówimy coś, co wygląda na konstatację, ma to specjalny, komunikacyjny sens.

Aleksy Awdiejew: Ależ to nie są konstatacje, to nie są w ogóle wypowiedzenia! To są konstrukty.

Jolanta Antas: Zgodzę się, są to konstrukty. Komunikatywizm nie powinien zajmować się konstruktem, lecz wypowiedzią językową. To jest różnica w naszym pojmowaniu komunikatywizmu. Aczkolwiek jest to sprawa dyskusyjna.

Aleksy Awdiejew: Dlaczego biedny komunikatywista zajmuje się konstruktem? Chętnie nie zajmowałbym się nim, chcę tylko odpowiedzieć na pytanie, jak człowiek kojarzy i jak interpretuje to, co słyszy, na czym polega funkcjonowanie tego mechanizmu. Interesujące jest to, jak mamy zapisywać znaczenie. Wyobraźmy sobie sytuację, że stwarzam program komputerowy, który opisałby, co wyraziłem i ocenił, czy jest to trywialne, czy nie. Wpisałbym do komputera wszystkie konstrukty, o których przed chwilą mówiliśmy. I rzeczywiście, okazałyby się trywialne. Są to stwierdzenia, które nie komunikują niczego poza naszą wiedzą o świecie i zazwyczaj ich nie wypowiadamy. Ale nie znaczy to, że nie mam 
prawa się tym zajmować; jako komunikatywista chcę określić wartość komunikacyjną, muszę wiedzieć, co jest komunikacyjne, a co nie (choć to niewdzięczna praca).

Jeśli nie możemy ustalić granicy między semantyką a tzw. pragmatyką, oznacza to, że mamy do czynienia z nieadekwatną teorią języka. Niestety, zgadzam się z Malinowskim, że w swojej pierwotnej funkcji język w ogóle nie referuje rzeczywistości jako takiej, ani też jej nie przywołuje. Język służy do organizacji wspólnych działań ludzi - odbywa się to w pierwotnej sytuacji pragmatycznej, kiedy ludzie nie przywołują nazw z pamięci, tylko wskazują na nazwy istniejące wokół nich. Jest to pierwsza rzecz, która wskazuje na istnienie języka w świadomości człowieka. Przejście do poziomu refleksji, przywoływanie nazw z pamięci, jest ogromnym osiągnięciem ludzkości, które pojawiło się znacznie później miliony lat rozwoju były potrzebne do zaistnienia takiej możliwości. Najczęściej używamy języka w pierwotnej sytuacji pragmatycznej: ,podaj mi tę szklankę”, „weź to” itd. Zgodnie z koncepcją Malinowskiego jest to pierwotna funkcja języka - i z tym się zgadzam bezsprzecznie. To nie jest jeszcze poziom semantyczny; jeśli zastanowimy się, gdzie zaczyna się semantyka, to dojdziemy do wniosku, że zaczyna się na poziomie refleksji, kiedy my konstruujemy jakieś obrazy, których nie widzimy, nie wskazujemy tego - konstruujemy. A więc dla mnie na przykład w gramatyce komunikacyjnej granica między semantyką (w tym sensie właściwym, jak ja to rozumiem) i pragmatyką leży na granicy właśnie ideacji i interakcji. Jeżeli ja mówię - co ja powiedziałem, to jestem w semantyce. Prawda? To znaczy, mówię: „książka leży na podłodze” - jestem w semantyce, to jest opis pozycji książki i każdy to zrozumie, bo wie, o co mi chodzi, może nawet to sobie wyobrazić, narysować, namalować i tak dalej.

Natomiast jeżeli zadaję pytanie: po co ja to mówię? To, rzeczywiście, muszę najpierw określić cel komunikacyjny. Więc w sytuacji komunikatywisty takiego, który tworzy dopiero metodę, muszę odpowiedzieć na pytanie, jakie są typowe reakcje na to, kiedy mówię: „książka leży na podłodze”. Ja robię ze swoimi studentami takie testy: co to znaczy, po co ja to mówię; osiemdziesiąt procent z nich mówi, że trzeba książkę położyć, gdzie trzeba. Nie wiem, dlaczego tak jest. Ja po prostu pytam i robię takie eksperymenty. Ja szukam. Ale oczywiście dopuszczam to, że można stawiać niezliczoną ilość różnych pytań i będą wtedy inne interpretacje. Ale ja muszę najpierw wychwycić te, że tak powiem, podstawowe, to znaczy prototypowe, a resztę uznać za peryferyjne. Ale to nie jest już dla mnie semantyka, ponieważ ona nie reprezentuje świata, ona reprezentuje układ interakcyjny: co kto ma robić. A jeżeli nazwiemy to semantyką, to to jest inny typ semantyki. Inny, zupełnie inny typ. I ja 
bym go nie chciał mieszać z semantyką ideacyjną, kiedy my po prostu zatrzymujemy się na prezentacji świata.

Pamiętam bardzo dobrą dyskusję o tym, jak niektóre frazeologizmy przebijają się na poziom interakcyjny, chociaż same coś też reprezentują, w sensie reprezentacji świata. Jeżeli ja mówię: ,jakiś matoł przyszedł”, to ideacyjnie mówię, że to jest chłop, w średnim wieku mężczyzna, w każdym bądź razie - to jest ideacja. Natomiast użycie słowa „matoł” już porzuca tę tradycyjną semantykę i zaczyna przebijać się na interakcję - ja go deprecjonuję po prostu. I to ja robię, to znaczy używam systemu, bo w systemie oczywiście wpisane jest, że „matoł” jest znakiem deprecjonującym. To jest moja wolna wola, że ja go tak traktuję. On nie zasługuje na to, ale ja to robię. I to nie jest przewidziane przez system. To jest interakcja, takie nieprzewidziane użycie.

Teraz uwaga do koleżanki Maćkiewicz: nigdy nie mówimy, że metafora jest dewiacją. Absolutnie nie. Jest to niestandardowa substytucja wewnątrz standardu. To znaczy, że niektóre niestandardowe substytucje są utarte, na przykład: ,zegarek chodzi”, „czas płynie”. To są standardy, bo one są już skonwencjonalizowane. Bo ontologicznie „płynąć” może oczywiście tylko płyn. Ale my to tutaj jakby zatrzymujemy i nie uważamy tego nawet za metaforę, my to odbieramy po prostu jak ,gotowiec”. Nie mamy elementu tworzenia.

Inna jest sytuacja, kiedy jest metafora twórcza. Kiedy ktoś mówi: „ściana płacze”, wtedy zastanawiam się: „co on chciał powiedzieć, co to jest: ściana płacze”. I zaczynam szukać pomostu styczności sensów, bo wiem, że płakać może tylko człowiek, albo żywa istota. Więc ja tę ścianę ,animalizuję”, jak my mówimy. Ona płacze i ja zaczynam szukać stycznego sensu. Stycznym sensem dla ściany jest wilgoć. Ja do tego dochodzę po prostu, żeby w ogóle zrozumieć, dlaczego on mówi: „ściana płacze”. A ściana może być mokra. To jest dopuszczalne standardowo. Więc to jest jedyna sytuacja, kiedy podejmuję interpretacyjny wysiłek. Natomiast: w przypadku metafory „dziewczyna rozkwita”, to jest potencjalne porównanie do roślinki - to jest, ,wegetatywizacja”. Tu ja tego wysiłku już nie podejmuję, bo ten wysiłek został już podjęty przez całe pokolenia, ja idę utartymi szlakami i już tego interpretacyjnego wysiłku nie robię. Ale ja wiem, że rozkwitać może roślinka, kwiat i to jest ontologiczna podstawa.

Uważam, że gramatyka musi mieć zdolność rozróżnienia, jakie wypowiedzenie jest trywialne, a jakie jest bardziej komunikacyjne w sensie systemowym. Istnieją tautologie: „kobieta jest kobietą”, „mężczyzna jest mężczyzną”, które w sensie logicznym uważane są za niemające żadnej wartości - a to nieprawda, oczywiście. Dlatego, że ta kobieta indeksowana na pierwszym miejscu to jest konkretna kobieta, o której mówimy, a kobieta na drugim 
miejscu jest zbiorem standardowych cech kobiety typowej. I to dlatego taka interpretacja pozwala zrozumieć, że ta tautologia ma sens i wartość komunikacyjną.

Jolanta Antas: Z tego wynikałoby, że niestandardowe, nietrywialne jest wszystko to, co mówimy, a trywialne jest to, co powiedzieliśmy.

Elżbieta Tabakowska: Chciałabym zacząć od podziękowania pani Profesor Maćkiewicz za postawienie pytania, na które wszakże nie padła odpowiedź. A jest ono początkiem, jak sądzę, całej tej dyskusji: kognitywizm - ale jaki? Bo przecież wszyscy państwo są kognitywistami. Jeszcze bardziej niż Guillaume, który był kognitywny inaczej. Ale jednak był kognitywistą, prawda?

Rzecz w tym, że mentalizm Chomsky’ego zakładał, iż opis języka jest opisem działania ludzkiego umysłu. I to miało konsekwencje. Cała gałąź językoznawstwa wyrosła z tego założenia. Tymczasem kognitywizm Langackerowsko-Lakoffowski jest czymś innym mówi, że opis języka jest opisem ludzkiego poznania. Stąd drugie terminologiczne nieporozumienie. Tak mi się przynajmniej wydaje: część z Państwa mówi o językoznawstwie, a inni o gramatyce, a to jest daleko nie to samo.

Gramatyka komunikacyjna to nie jest językoznawstwo komunikacyjne. Tak samo jak gramatyka kognitywna nie jest językoznawstwem kognitywnym. I to jest bardzo istotne rozróżnienie. Pani Profesor Antas w swoim wystąpieniu do niego nawiązała, prawda? Postulatem Langackera było - jeżeli dobrze pamiętam - żeby wszystko to, co zrobiono w pragmalingwistyce, $\mathrm{w}$ teorii relewancji $\mathrm{i}$ w funkcjonalizmie, próbować dobudować, nadbudować nad tym, co on stworzył. Langacker, oczywiście, nie mógł zajmować się pragmatyką, bo ktoś, kto czyta w wolnych chwilach Scientific American, nie może tego robić z definicji i z natury rzeczy, prawda? Widział natomiast tę konieczność. Mówił również, że granica między semantyką a pragmatyką jest umowna, ale sam zachował się jak agresor pierwszej wody. On usiłował pragmatykę ,wessać” w semantykę. I byłoby bardzo dobrze, gdyby komunikatywizm nie ,wsysał” semantyki w pragmatykę, dochodząc do momentu, w którym ta semantyka jest już „obcięta” i gdzieś wyrzucona. W tym chyba leży sedno tego, co Pan Profesor Awdiejew był łaskaw nazwać „,relacją, czyli kolizją”. Rozumiem, że zastosował Pan metaforę SPÓR TO WOJNA, czyli ARGUMENT TO WOJNA, lecz stawianie spójnika czyli między termem relacja a termem kolizja mnie się od początku, zwłaszcza $\mathrm{w}$ tym kontekście, nie podobało. Bo myślę, że owa relacja jest takim wstępnym, wzajemnym badaniem gruntu. 
Właściwie miałabym ochotę wejść z kolegami w spór (nie wojnę!), wbrew wszelkim metaforom, właściwie tylko w dwóch sprawach. Po pierwsze, chciałabym, żebyśmy się zastanowili i ustalili, czy my się zajmujemy produktem, czy my się zajmujemy procesem. Ja jestem translatologiem (jeżeli taka dyscyplina w ogóle istnieje), i wiem, że od tego trzeba zacząć. A my tego sobie jak dotąd wcale nie wyjaśniliśmy. Po drugie: chcę, żeby Państwo, przyglądając się światu i relacjom, zechcieli rozważyć możliwość, że te relacje zachodzą między czymś a czymś. I że te „cosie”, między którymi powyższe relacje zachodzą, mają swoją autonomiczną rację bytu. Rzecz istnieje sama w sobie. Ziemniak to jest ziemniak, i jest to tylko ziemniak. I wcale nie pociąga za sobą konieczności ani jedzenia, ani pieczenia, ani obierania. Natomiast obierać trzeba „coś”. Ja nie wiem wielu rzeczy, ale wiem, czym są przedmioty. Ja nie wiem, co się robi z kwarkami, ale wiem, co to jest kwark - bo znam definicję. A ziemniak nie wymaga relacji mojej z ziemniakiem ... ani niczyjej innej.

I to mnie prowadzi do następnej propozycji. Nam, kognitywistom, brakuje tego, co Państwo robią i dlatego powinniśmy Wam wyjść naprzeciw. Natomiast Państwu brakuje pełniejszego oparcia w tych teoretycznych osiągnięciach, do których ci nudni kognitywiści, teoretycy języka i gramatyki, doszli. Oni widzą schematy wyobrażeniowe nieco inaczej niż widzą je Państwo, ponieważ oni nie wychodzą od standardu, tylko od psychologii kognitywnej. I dlatego w ich opisach istnieje - między innymi - jeden z podstawowych schematów wyobrażeniowych, który wygląda następująco: ŹRÓDŁO-ŚCIEŻKA-CEL. Gdyby zastanowić się nad tym schematem, to wtedy można by pewnie zechcieć twierdzić, że przyjechać to jest nie tylko dokądś ktoś, ale również skąd. Tenże standard - zaczerpnięty jako przykład z wystąpienia pani Profesor Habrajskiej - jest jakby niepełny, co widać gołym okiem. Dlaczego przyjechać ktoś dokądś jest uprawnione, a przyjechać ktoś skądś nie jest uprawnione?

Aleksy Awdiejew: Nie jest to obligatoryjnie oznaczone.

Elżbieta Tabakowska: Ale chodzi o całość schematu! I to mnie prowadzi już prosto do metafory, która łączy się z profilowaniem. Gdyby Państwo komunikatywiści zechcieli spojrzeć na to, co się w kognitywnej gramatyce mówi o profilowaniu, to od razu widzieliby nie tylko dlaczego przyjechać-przyjazd-przyjezdny itd. powinny się znaleźć razem. Byłoby też wiadomo, dlaczego we wszystkich występuje właśnie przy-, a nie jakiś inny przedrostek. I tego właśnie brakuje mi wyraźnie w Państwa podejściu do słowotwórstwa. To też jest metafora, to przy-jechanie (dokądś): bo efektem działania może być także metaforyczne 
„bycie przy czymś”. Twierdzę, że i przyjechać skądś może być metaforą: przyjechat z niewoli. Ja wiem, że Państwo metaforę uznają, ale uznają ją przyjmując konwencjonalną definicję metafory. Taką, jaką się przyjmowało w tradycyjnej teorii literatury. W swoim dzisiejszym wystąpieniu Pani Profesor Maćkiewicz proponowała Państwu rozszerzenie trochę tego spojrzenia. Przy-w przyjechać jest równie metaforyczne, jak ta ściana, co płacze, tylko o wiele bardziej skonwencjonalizowane. Uznanie wszechobecności metafory pozwala wyjaśnić sporo spraw, które na tym etapie pozostają niewyjaśnione.

Chciałabym zakończyć pytaniem do Pana Profesora Awdiejewa, naprawdę szczerym pytaniem. Proszę o szczerą odpowiedź. Jaka jest definicja trywialności? Co to jest za kategoria i jak się ją definiuje? I to chyba wszystko. Dziękuję państwu bardzo i przepraszam, że się wepchnęłam bez kolejki.

Aleksy Awdiejew: Zgadzam się, że powstaje pewne nieporozumienie. Naszym celem jest odpowiedź na pytanie: co ja komunikuję, kiedy mówię przyjechać, ktoś przyjechat. Obligatoryjnie muszę podać gdzie. Bo jeżeli nie podaję i mówię np. „Janek przyjechał”, to sytuacyjnie wiem, że przyjechał tu. Krótko mówiąc, w tym, co zostało zakomunikowane, nie komunikuje się skąd. Nie wiem, dlaczego. Schemat jest, owszem: że się urodził, że gdzieś był, że jechał i dojechał, ale minimalny komunikat nie mieści tego. Można to wyspecyfikować: Na przykład, komunikat „Jola przyjechała” eksponuje gdzie (nie skądś) i wiem, że tu. Możemy się zgadzać albo nie, ale my mamy inny cel - nie wiem, jak kognitywne profilowanie można sformalizować. A my chcemy i musimy je sformalizować. Musimy mieć jednostki. Jeżeli będę pracować na konceptach, to nie wprowadzę ich do komputera, nie zapiszę ich w programie.

Elżbieta Tabakowska: Jest jakaś różnica między zapisem celu a źródła? Formalnie da się to zapisać. Skoro zapisuje się cel, to dlaczego nie można zapisać źródła?

Aleksy Awdiejew: Dlatego, że przyjechać jest zdarzeniem - ktoś zaczął jechać, jechał i dojechał, przyjechał. To ja komunikuję na pewno. Natomiast skąd - tam tego nie ma. Domyślam się, że skądś przyjechał, ale nie jest to wyznaczone komunikacyjnie.

Jolanta Antas: Jeśli to ma być schemat wyobrażeniowy, to na niego składa się całość. Związany jest z tym fakt, że ktoś skąd, gdzieś zaczął, ruszył. 
Aleksy Awdiejew: To i tak nic nie zmienia, jeśli ja do maszyny te informację automatycznie wrzucę, to i tak będzie to samo. Maszyna mnie zapyta: Dobrze, skąd przyjechał, a ja powiem: Nie było to zakomunikowane. To jest bardzo trudny problem, który wymaga osobnej dyskusji.

Jolanta Antas: Maszynie można wtedy powiedzieć, to nie było ważne, wymaż sobie ten argument. Ale bardzo proszę o odpowiedź na pytanie, które nas frapuje: co to jest trywializacja?

Aleksy Awdiejew: Ja mówiłem o Ajdukiewiczowskim K jak Knowledge (wiedza) i P jak Propozycja. Ajdukiewicz mówił, że kwantyfikator K znaczy „wszyscy wiedzą że...”, a P wyraża treść tej informacji, o której wszyscy wiedzą. A więc, jeżeli wszyscy wiedzą o czymś, to nie używają tej wiedzy. A jeżeli używają, czyli mówią o tej wiedzy, to musimy zrobić reinterpretację tego, co oni mówią, bo inaczej to nie ma wartości informacyjnej. My reagujemy: „A, już wiem”, to znaczy „Niepotrzebnie mi to mówiłeś, bo już o tym wiem”. Natomiast w przypadku, kiedy my tego kwantyfikatora K używamy w sensie „każdy wie, że", to wtedy, jeśli ja wiem, że on wie i wszyscy wiedzą, że człowiek ma dwoje uszu, jeden nos, że chodzi przy pomocy nóg, to wtedy werbalizacja tego rodzaju treści jest tym poziomem trywialności, o którym ja mówię.

Elżbieta Tabakowska: „Standardy semantyczne istnieją.” Czy to jest standard semantyczny?

Aleksy Awdiejew: Jest, ponieważ ,istnieć” przyjmuje wszystkie argumenty, nawet rzecz sama w sobie istnieje.

Elżbieta Tabakowska: Wszyscy wiedzą, że standardy semantyczne istnieją? Ja pytam na poziomie meta.

Aleksy Awdiejew: Nie, jeśli o to chodzi, to jest specjalistyczne zdanie, to nie jest standard semantyczny języka polskiego. Może to być standardem jakiejś odmiany języka ludzi, którzy się tym zajmują. Ponieważ standardy mogą być środowiskowe. Oczywiście. I nawet między nami może powstać jakiś standard, o którym my nie będziemy mówić. My badamy tylko systemowe standardy. 
Aleksander Kiklewicz: Stanowisko pana Profesora Awdiejewa wydaje mi się zupełnie logiczne. Powinniśmy to byli określić na początku. Trywialność, czyli standardowość, czyli presupozycje epistemiczne, tzn. presupozycje typu „Każdy wie, że...” - należą do apercepcyjnej bazy danej społeczności czy też grupy społecznej. Są one przyjęte przez daną społeczność, znane przez jednostki, więc nie zawierają informacji - w matematycznym znaczeniu tego słowa (informacji jako entropii). Komunikacja, czy też kryterium komunikacyjne, staje się więc tym kryterium, które pozwala na wyeksplikowanie takich standardów kognitywnych. I tu jest, moim zdaniem, pole współpracy komunikatywistów i kognitywistów. Prawdopodobnie chodzi nam w tej dyskusji o szczegóły tej współpracy, nie zaś o istotę rzeczy, bo w kwestii zasadniczej, jak się zdaje, generalnie się zgadzamy.

Jolanta Maćkiewicz: Może dodam coś jeszcze o standardach. Jak rozumiem, standardy wykorzystują stereotypy, oczywiście w szerokim, niesocjologicznym, czyli nieodnoszącym się tylko do grup ludzkich sensie, to znaczy - stereotypy, które mogą być związane z obiektami konkretnymi; ale jak to się ma do pojęć abstrakcyjnych? Przytoczmy jakieś standardowe zdanie, na przykład z demokracją: „demokracja jest największym dobrem”. Tutaj stereotypizację jest znacznie trudniej odróżnić od tego, co niestereotypowe; jak będzie zatem ze standardami w odniesieniu do abstrakcyjnych pojęć, gdzie stereotypy, jeżeli istnieją, mają zasięg wąskogrupowy? Jak to rozstrzygnąć?

To jest jedna rzecz. Druga rzecz to standardy a schematy pojęciowe czy modele pojęciowe - jakkolwiek to nazwiemy, bo kognitywiści posługują się różną terminologią. To jest znacznie bardziej skomplikowane. Jeżeli zakłada się, że sens słowa rozumiany jest na tle całego, rozbudowanego modelu pojęciowego, wówczas przycinanie modeli pojęciowych czy schematów do standardów może zafałszować to, jak my naprawdę myślimy czy posługujemy się słowami.

Aleksy Awdiejew: Jak mówiłem, my nie mamy wyjścia. Redukujemy nasze wyobrażenia do jednostek, które są predysponowane do werbalizacji. Nasze wyobrażenia są znacznie bogatsze i skomplikowane, ale to jest poziom poznawczy, jak słusznie Pani Profesor zauważyła. Różnice między poziomem poznawczym a zbiorem standardów semantycznych przejawiają się w znaczeniu leksykalnym czy morfologicznym, i w ogóle - gramatycznym języka, bo tak samo jak Guillaume i wszyscy funkcjonaliści uważamy, że wszystko komunikuje. Co komunikuje? Do czego się odnosi? W języku nie ma niektórych standardów, na przykład: węchowych czy wzrokowych, ornamentów itd., które w danym społeczeństwie 
istnieją. Przejawiają się one w innych dziedzinach, ale nie w języku. Niektóre rzeczy trudno zwerbalizować i my o nich nie mówimy, a możemy, specyfikując na poziomie właśnie komunikacyjnym, dodać różne specyfikacje naprowadzające na te standardy. Wtedy, nie wiem, nie badałem tego... Rzeczywiście, tak jak mówiłem: to sprawa określenia standardów semantycznych.

Co to jest, na przykład: trywialność, banalność? Można tym się nie zajmować, oczywiście. My jesteśmy zmuszeni do tego, bo musimy ustalić poziom wartości komunikacyjnej. To nie jest nawet ilościowa sprawa, tylko właśnie określają to potrzeby komunikacyjne człowieka, ludzi, którzy się ze sobą komunikują. „Demokracja jest najlepszą rzeczą" - to jest banał, który można by uznać za prawdę albo nieprawdę, ale ja tego nie wiem, nie mogę odpowiedzieć na to pytanie. Jest to rzeczywiście trudna sprawa; będziemy nad tym pracować.

Grażyna Habrajska: Ja mam uwagę do Pani Profesor Antas. Powiem tak: może jest jakaś szansa na zbliżenie w tych naszych badaniach, ale jeden problem jest zasadniczy, że jednak kognitywizm, jak do tej pory deklaruje zajmowanie się słowem. A my jednak nie - nie widzimy znaczenia pojedynczego słowa. No, jeżeli już z tego rezygnujecie, to się cieszymy strasznie. Bardzo się cieszę. Natomiast, żeby postawić kropkę nad „i”: nie ma oczywiście interakcji bez ideacji i dlatego musimy ideacją się zajmować. Nie ma oddzielenia; w ogóle nie istnieje interakcja bez sensów ideacyjnych. Bo nawet, jeżeli nie ma zwerbalizowanej treści ideacyjnej, to ją zastępuje sytuacja użycia i ideacja musi być przy interakcji. Tutaj nie ma chyba wątpliwości.

Ja nie chciałam powiedzieć, że przywołujemy wszystkie możliwe asumpcje i dopiero następuje mechanizm reinterpretacji. Asumpcja się pojawia w zależności od tego, w jakiej sytuacji komunikacyjnej się znajdujemy. Ona sama się nam nasuwa czy narzuca, w zależności od tego, jaka jest relacja między interlokutorami, to też im się narzuca. A to oczywiście nie jest przywoływanie całego zestawu wszystkich asumpcji właśnie. Tak samo chyba nikt by nie chciał powiedzieć, że kiedy mówimy o znaczeniu słowa, to wszystkie znaczenia tego słowa naraz w głowie nam się pojawiają. I chyba też kognitywista czegoś takiego nie chciałby powiedzieć, prawda? Tak, to nie jest tak, jak mówi tu pani Profesor Antas, to nie jest odrzucanie, tylko weryfikowanie.

Natomiast jeśli chodzi o ten spór ze schematem, to my po prostu przyjmujemy minimalny kawałek schematu, ale można powiedzieć, że jest to wyprofilowanie, tak jak pani Profesor Tabakowska chciała, wyprofilowanie fragmentu schematu. My chcemy nazywać te 
schematy minimalne standardami - chodzi o to, co musi się pojawić. I przy przyjechać musi się pojawić gdzie. A nie musi się pojawić skąd, może, ale nie musi. A gdzie musi być. I my chcemy mieć tylko takie schematy, gdzie mamy to, co „musi” być. A co „może”, to jest następna sprawa. „Może” być bardzo dużo, bo my mamy nieograniczone możliwości rozszerzania czy kreatywności w języku. Także tu można bardzo dużo dodawać i uzupełniać i wiele standardów w to włączyć.

Barbara Bacz: Ja tylko chciałam podziękować pani Profesor Antas. Oczywiście, nie suma aktualizacji, lecz profilowanie. Pytanie jest takie: w jaki sposób odbywa się profilowanie? Guillaumiści usiłują się zastanowić nad tym, na czym polega mechanizm profilowania. Nie tylko, że coś jest uwypuklane na innym tle, ale również, jak to się odbywa. I proponują różne mechanizmy, między innymi mechanizm na linii czasu, przecinanie różnych momentów, zatrzymywanie obrazów w jednym momencie. Także za to serdecznie dziękuję.

A czy język jest najpierw wyrażeniem, a później komunikacją? Chciałam przypomnieć, że istnieją takie użycia u dzieci, że dziecko biega, gdzieś to wyczytałam, mogę znaleźć u takiego teoretyka literatury Bakera, który pisał: biega dziecko po pokoju i woła „Pies! Pies! Pies!", i nic nie chce powiedzieć. Nie chce nam powiedzieć, że pies przyszedł czy wyszedł. Chce nam powiedzieć, że zrozumiało, co to znaczy pies i dlatego się cieszy i powtarza to słowo w kółko. To znaczy zrozumiało pewien koncept. Czy wartość komunikacyjna tego polega na tym, że: chcę wam powiedzieć, że zrozumiałem pewien koncept? Być może. Albo można powiedzieć, że konceptualizacja jest też ważna i że to jest jakiś zewnętrzny dowód na to, że pojęcia się konceptualizuje i nadaje się im nazwę w pewnym momencie. Jak już coś tam wiemy.

Jolanta Antas: Myślę, że to jest pozorne nieporozumienie. Ja w ogóle nie chciałam mówić, broń Boże negować w ogóle roli języka w konceptualizacji. Tylko chciałam powiedzieć, że konceptualizacja jako proces może zachodzić bez języka, to znaczy tylko tyle, że po prostu w momencie, kiedy człowiek mówi sam do siebie na przykład, a ja bardzo często tak mówię do siebie, nawet sobie wydaję różnego rodzaju instrukcje na głos, nawet spory toczę ze sobą - to wtedy wiem, że jestem w sytuacji komunikacyjnej wewnątrz siebie. I to dziecko radujące się zrozumieniem konceptu też daje temu wyraz jakby przed sobą, bo ono wtedy dialogizuje. I stąd chciałam powiedzieć, że język o tyle jest środkiem komunikacji o ile jest środkiem dialogiczności myśli, i dlatego nie chcę tego jednego od drugiego oddzielać - nie mówić, 
które pierwotne, które wtórne, że to tak po prostu jest. Jest wyrazem naszych myśli, więc dialogiem, a więc i komunikacją równocześnie.

Jolanta Maćkiewicz: Tylko takie uzupełnienie. Z drugiej strony: język nie jest dla komunikacji niezbędny. Jesteśmy w stanie porozumiewać się niewerbalnie, natomiast dla opisywania świata język jest niezbędny.

Jolanta Antas: No, niezbędny jest nie dla opisywania świata, tylko dla zdolności pojmowania epistemicznego, jakby uszeregowania tego świata, bo też go możemy percypować bez języka, ale nie obrabiać, jakby oswajać. Na to nam jest język potrzebny, żeby oswajać sobie świat.

Aleksander Kiklewicz: Dziękuję bardzo. Proszę państwa, ponieważ prawie wyczerpaliśmy czas naszej dyskusji, pozwoliłbym sobie jedynie na krótki komentarz oraz na podsumowanie. Mam wrażenie, że dyskusja potwierdziła moje wstępne założenia, że kognitywiści skłonni są raczej lekceważyć czynnik komunikacyjny działalności językowej, podczas gdy stanowisko komunikatywistów jest nie tylko ambiwalentne, ale ponadto skłonni są oni (paradoksalnie) wyolbrzymiać czynnik kognitywny, przede wszystkim jeśli chodzi o opis komunikacji interpersonalnej - obawiam się, że w tym przypadku komunikację językową utożsamia się z dialogową komunikacją interpersonalną face to face. Dlaczego twierdzę, że kognitywiści raczej lekceważą czynnik komunikacyjny? W odróżnieniu od pani Profesor Jolanty Maćkiewicz, nie uważam teorii metafory pojęciowej Lakoffa i Johnsona za teorię adekwatną dla materiału języków naturalnych, ponieważ nie odzwierciedla ona istoty rzeczy -

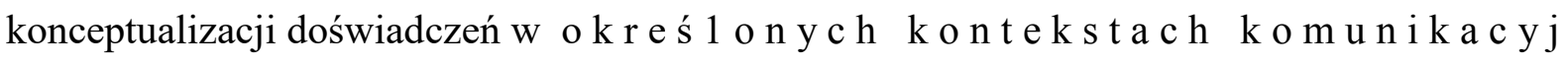
$\mathrm{n}$ y c h. Chodzi mi przede wszystkim o to, że jest bardzo dużo aspektów komunikacyjnych metafory jako zjawiska językowego, semantycznego, i metafory jako zjawiska psychicznego, konceptualnego, których teoria Lakoffa i Johnsona po prostu nie uwzględnia. Nie uwzględnia np. zjawiska idiosynkrazji metafor, które wręcz koliduje z kognitywistycznym postulatem uniwersalności (pisze o nim w szczególności Olaf Jäkel). Teoria Lakoffa i Johnsona oparta jest na metaforach konwencjonalnych, „codziennych”, ale bardzo często jest to konwencjonalność pozorna. „Poradnik językowy” chyba najbardziej regularnie ze wszystkich polskich periodyków lingwistycznych zamieszcza artykuły na temat metaforycznej konceptualizacji świata, np. konceptualizacji emocji, ale badacze nie zauważają faktu, że wiele $\mathrm{z}$ tych metafor ma charakter rzadki, a przede wszystkim idiosynkratyczny - 
nacechowany komunikacyjnie. W swoim referacie przeanalizowałem tylko jeden taki przykład: Rodziców opanowała radość. A jest ich sporo. Wyrażenia metaforyczne budzić gniew, dawaćldać pierwszeństwo, obdarzaćlobdarzyć uczuciem, obdarzaćlobdarzyć władza, obdarzać/obdarzyć współczuciem, oddawać/oddać uścisk dłoni, odnosićlodnieść zwycięstwo, ponosić/ponieść klęskę, składać/złożyć obietnice i in. nie wydają się charakterystyczne dla sfery naturalnej komunikacji codziennej, choć oczywiście są również takie wyrażenia metaforyczne, którym przysługuje odmienna cecha stylistyczna: potoczność.

Kognitywiści, jak się wydaje, nie uwzględniają faktu, że wiele metafor językowych, przede wszystkim książkowych, oficjalno-urzędowych, ma charakter zapożyczeń. W tym przypadku można wątpić, czy u podstaw takich metafor w języku leżą kognitywne procesy rzutowania (mapping). Kognitywiści powołują się na psychiczną motywację aktywności językowej. Wątpię, żeby w przypadku takich nominacji wchodziła w grę motywacja, czy proces rzutowania. Wyrażenia metaforyczne są zapożyczane jako skonwencjonalizowane, gotowe formy nominacji, natomiast ich funkcjonowaniu w komunikacji językowej towarzyszą konotacje stylistyczne: książkowy, urzędowy, potoczny itd. Współczesnym teoriom kognitywistycznym, a także ufundowanym na nich heurystykom można zarzucić pewien brak podobnej informacji.

Komunikatywizm, jak się wydaje, nieraz (jak wspomniałem powyżej) wyolbrzymia czynnik kognitywny komunikacji językowej. O ile stosownie interpretuję wystąpienie pana Profesora Awdiejewa, a także niektóre jego wcześniej opublikowane teksty, system konceptualizacji w pragmalingwistycznej koncepcji języka znajduje się wewnątrz języka, utożsamia się z semantyką. Otóż jestem zwolennikiem odmiennej, z dzisiejszego punktu widzenia tradycjonalistycznej koncepcji, głoszonej przez moskiewską szkołę semantyczną, a w szczególności przez Jurija Apresjana. Zgodnie z tą koncepcją językowe (systemowe według Bartmińskiego) znaczenie znaku to jest sens minus kontekst. $Z$ tego punktu widzenia sens (czy też treść) składa się ze znaczenia i konotacji. Konotacje istnieją poza językiem i są czymś, co jest spowodowane kontekstem.

Traktowanie semantyki jako konceptualizacji nieraz poważnie komplikuje opis znaczenia. Tak więc w koncepcji profilowania Jerzego Bartmińskiego, z jednej strony, profil stanowi jeden $\mathrm{z}$ aspektów znaczenia wyrazu, występuje wewnątrz znaczenia. Z drugiej strony, Bartmiński rozróżnia np. cztery profile Niemca (tj. cztery historyczno-kulturowe konotacje pojęcia „Niemiec”), które - zgodnie z definicją pojęcia „profil” - należałoby potraktować jako cztery elementy składowe z n a c z e n i a 1 e k s y k a $1 \mathrm{n}$ e g o Niemiec. Ponieważ profile w tym przypadku odzwierciedlają historyczno-kulturowe style myślenia, 
więc zmianę profilu trzeba by traktować jako zmianę znaczenia. Byłoby to jednak sprzeczne z realnością komunikacji językowej, jako że interpretacja semantyczna rzeczownika Niemiec np. w wyrażeniu Niemiec nadal siedziat na ławce będzie zasadniczo jednakowa niezależnie od historyczno-kulturowego stylu myślenia. Można wątpić, czy w tym, referencyjnym użyciu rzeczownika, przy minimalnym oddziaływaniu czynników kontekstowych (w szczególności kulturowych), konotacja aksjologiczna (wartościowanie) w ogóle się uaktywnia.

Bardzo upraszczając, można rozróżnić trzy koncepcje znaczenia we współczesnym językoznawstwie. U podstaw pierwszej, tradycyjnej i, moim zdaniem, logicznie niesprzecznej i praktycznie najbardziej przydatnej koncepcji leży idea: znaczenie to jest sens minus kontekst. Druga koncepcja, kognitywistyczna, bazuje na koncepcji: znaczenie to jest sens. Jest to holistyczne, encyklopedyczne ujęcie znaczenia - znaczenie wyrazu równoznaczne jest z wiedzą o odpowiednich obiektach. I wreszcie trzecia koncepcja pragmalingwistyczna. Jej założenie można określić następująco: znaczenie to jest kontekst. Jest to synergiczna koncepcja języka, wywodząca się głównie z pragmalingwistyki Wittgensteina, a także $\mathrm{z}$ angielskiej szkoły analizy dyskursu.

Na zakończenie chciałbym podkreślić, że bardzo naturalne jest to, że konferencja, która ma tytuł ,Język trzeciego tysiąclecia”, omawia także perspektywy j ę z y k o z n a w s t w a t r z e c i e g o t y s i ą c 1 e c i a. Dzisiejsza dyskusja wykazała, że między kognitywizmem a komunikatywizmem istnieją poważne różnice metodologiczne, odmienne sposoby traktowania tych samych obiektów lingwistycznych, a nawet sposoby określenia tego, co jest obiektem lingwistycznym. Pani Profesor Tabakowska zwróciła uwagę na fakt, że pewne kolizje są także wewnątrz kognitywizmu - mówiła o różnych „kognitywizmach”. A jednak nie brakuje także prób syntetycznego ujęcia socjologicznych i psychologicznych aspektów języka. Powołałem się w swoim referacie na teorię Kintscha i van Dijka, na teorię Sperbera i Wilson, na kognitywistyczne ujęcie semantyki tekstu w pracach pani Profesor Tabakowskiej i in. Badania w duchu pana Profesora Awdiejewa także znajdują się na pograniczu kognitywizmu i komunikatywizmu.

Pan Profesor Awdiejew przytoczył metaforę ściany. W moim tekście przywołałem inną metaforę: przypomnę, że na początku XX w. Jules Henri Poincare ironizował na temat badacza-naturalisty, który gromadzi wiedzę o słoniu jedynie na podstawie jego obserwacji pod mikroskopem. Kontynuując to porównanie wypada stwierdzić, że na początku XXI w. językoznawcy badają słonia raczej pod teleskopem. Z tym, że teleskopów jest kilka, a więc każdy obserwator widzi inny profil tego samego ,słonia”. 
Cel naszego spotkania, jak również cel wszystkich integracyjnych (uniwersalistycznych) poczynań we współczesnej filozofii języka polega na tym, aby te profile połączyć, w sposób zasadniczy skonfigurować. Takie ujęcie syntetyczne najbardziej odpowiadałoby antropologicznej, wielofunkcyjnej istocie języka. Pani Profesor Jolanta Maćkiewicz w swoim wystąpieniu podkreślała, że językoznawstwo to nauka o człowieku, a więc nie można ograniczyć się do opisu jego wybranych aspektów - językoznawstwo musi także wyjaśniać funkcjonowanie języka jako narzędzia komunikacji i jako narzędzia poznania świata. Być może pojęcie „lingwistyka” i pojęcie „lingwistyczny” w takim ujęciu w pewnym stopniu się rozprasza, ale nie ma tu zagrożenia. W związku z tym chciałbym przypomnieć stare, bo jeszcze $\mathrm{z}$ lat sześćdziesiątych XX w. powiedzenie Romana Jakobsona - nie tylko wielkiego strukturalisty, ale także wielkiego uniwersalisty: „Linguista sum - linguistici nihil a me alienum putto".

\section{Źródło}

Dyskusja po raz pierwszy została opublikowana w całości w 2006 roku w tomie Kognitywizm i komunikatywizm - dwa bieguny współczesnego językoznawstwa. Dyskusja przy okrągłym stole, pod redakcją Władysława Chłopickiego, Język a komunikacja 9, Kraków: Tertium. 